\begin{tabular}{|l|l|l||}
\hline \multicolumn{2}{|c|}{ PublisherInfo } \\
\hline \hline PublisherName & $:$ & BioMed Central \\
\hline \hline PublisherLocation & $:$ & London \\
\hline \hline PublisherImprintName & $:$ & BioMed Central \\
\hline \hline
\end{tabular}

\title{
Polymorphic Toll-like receptors
}

\begin{tabular}{|l|l|l||}
\hline \multicolumn{2}{|c|}{ ArticleInfo } \\
\hline \hline ArticleID & $:$ & 3574 \\
\hline \hline ArticleDOI & $:$ & $10.1186 /$ gb-2000-1-1-reports040 \\
\hline \hline ArticleCitationID & $:$ & reports040 \\
\hline \hline ArticleSequenceNumber & $:$ & 65 \\
\hline \hline ArticleCategory & $:$ & Paper report \\
\hline \hline ArticleFirstPage & $:$ & 1 \\
\hline \hline ArticleLastPage & $:$ & 3 \\
\hline \hline & & RegistrationDate : 2000-6-6 \\
ArticleHistory & $:$ & Received \\
\hline ArticleCopyright & $:$ 2000-6-6 \\
\hline \hline ArticleGrants & $:$ & OnlineDate \\
\hline \hline ArticleContext & $:$ & 130591111 \\
\hline \hline
\end{tabular}




\section{Abstract}

Genomic sequencing of the Toll-like receptor 4 gene in humans, mice, chimpanzee and baboon has shown that the Tlr4 protein is polymorphic.

\section{Significance and context}

The Toll-like receptor 4 (Tlr4) is thought to bind bacterial lipopolysaccharide (LPS), a structural component of the outer membrane of Gram-negative bacteria, and is thought to mediate LPS signal transduction in mammalian immune system cells. An understanding of interspecific and interindividual differences in LPS responses is important, as an appropriate response to LPS is now recognized as essential for the successful containment of infection. Smirnova et al. address this problem by sequencing the Tlr4 gene in humans and mice, and by also sequencing the coding region and splice junctions of Tlr4 from 35 mouse strains, chimpanzee and baboon. Information on the degree of Tlr4 polymorphism in these species will enable the importance of different Tlr4 domains in the LPS response to be assessed, as well as the effect of polymorphism on host innate immune defenses.

\section{Key results}

Smirnova et al. identified the genomic sequence of Tlr4 in human and mouse; both contain three conserved exons and lie amid repetitive sequences of retroviral origin. Analysis of Tlr 4 from 35 strains of Mus musculus revealed that Tlr4 is a polymorphic protein. The extracellular domain is far more variable than the cytoplasmic domain, although variability does not seem to be confined to any particular region of the extracellular domain. The carboxy-terminal end of the cytoplasmic domain is, however, also highly variable. The additional determination of the coding sequence of Tlr4 from chimpanzee and baboon showed that variation was evident among both strains and species.

\section{Reporter's comments}


The authors have identified a spectrum of naturally occurring mutation in murine Tlr4 and thus have provided a foundation for functional experiments to investigate the effects of this polymorphism on innate immunity. The next step is to determine whether, and how, the mutations discovered alter either the specificity of LPS detection or the magnitude of the LPS signal.

\section{Table of links}

Genome Biology

\section{References}

1. Smirnova I, Poltorak A, Chan EKL, McBride C, Beutler B: Phylogenetic variation and polymorphism at the Toll-like receptor 4 locus (TLR4). Genome Biology. 2000, 1: research002.1-002. 